NASA/TM-2010-216370

\title{
Thermal Stability Testing of a Fischer-Tropsch Fuel and Various Blends With Jet A
}

Jennifer Suder Klettlinger and Angela Surgenor

Glenn Research Center, Cleveland, Ohio

Chia Yen

University of Toledo, Toledo, Ohio 


\section{NASA STI Program . . . in Profile}

Since its founding, NASA has been dedicated to the advancement of aeronautics and space science. The NASA Scientific and Technical Information (STI) program plays a key part in helping NASA maintain this important role.

The NASA STI Program operates under the auspices of the Agency Chief Information Officer. It collects, organizes, provides for archiving, and disseminates NASA's STI. The NASA STI program provides access to the NASA Aeronautics and Space Database and its public interface, the NASA Technical Reports Server, thus providing one of the largest collections of aeronautical and space science STI in the world. Results are published in both non-NASA channels and by NASA in the NASA STI Report Series, which includes the following report types:

- TECHNICAL PUBLICATION. Reports of completed research or a major significant phase of research that present the results of NASA programs and include extensive data or theoretical analysis. Includes compilations of significant scientific and technical data and information deemed to be of continuing reference value. NASA counterpart of peer-reviewed formal professional papers but has less stringent limitations on manuscript length and extent of graphic presentations.

- TECHNICAL MEMORANDUM. Scientific and technical findings that are preliminary or of specialized interest, e.g., quick release reports, working papers, and bibliographies that contain minimal annotation. Does not contain extensive analysis.

- CONTRACTOR REPORT. Scientific and technical findings by NASA-sponsored contractors and grantees.
- CONFERENCE PUBLICATION. Collected papers from scientific and technical conferences, symposia, seminars, or other meetings sponsored or cosponsored by NASA.

- SPECIAL PUBLICATION. Scientific, technical, or historical information from NASA programs, projects, and missions, often concerned with subjects having substantial public interest.

- TECHNICAL TRANSLATION. Englishlanguage translations of foreign scientific and technical material pertinent to NASA's mission.

Specialized services also include creating custom thesauri, building customized databases, organizing and publishing research results.

For more information about the NASA STI program, see the following:

- Access the NASA STI program home page at http://www.sti.nasa.gov

- E-mail your question via the Internet to help@ sti.nasa.gov

- Fax your question to the NASA STI Help Desk at 443-757-5803

- Telephone the NASA STI Help Desk at 443-757-5802

- Write to: NASA Center for AeroSpace Information (CASI) 7115 Standard Drive Hanover, MD 21076-1320 


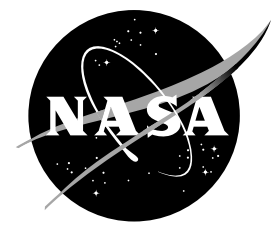

\section{Thermal Stability Testing of a Fischer-Tropsch Fuel and Various Blends With Jet A}

Jennifer Suder Klettlinger and Angela Surgenor Glenn Research Center, Cleveland, Ohio

Chia Yen

University of Toledo, Toledo, Ohio

National Aeronautics and

Space Administration

Glenn Research Center

Cleveland, Ohio 44135 


\section{Acknowledgments}

We would like to express our special appreciation to NASA Fundamental Aeronautics Subsonics Fixed Wing Project for funding this research, Laura Acosta, Summer Intern from Ohio State University, for completing some of the thermal stability tests, Dr. Tim Edwards for providing the fuel and fuel analysis data, and David Hull for tube surface optical imaging.

Trade names and trademarks are used in this report for identification only. Their usage does not constitute an official endorsement, either expressed or implied, by the National Aeronautics and Space Administration.

This work was sponsored by the Fundamental Aeronautics Program at the NASA Glenn Research Center.

Level of Review: This material has been technically reviewed by technical management.

Available from

NASA Center for Aerospace Information 7115 Standard Drive

Hanover, MD 21076-1320
National Technical Information Service 5301 Shawnee Road Alexandria, VA 22312 


\title{
Thermal Stability Testing of a Fischer-Tropsch Fuel and Various Blends With Jet A
}

\author{
Jennifer Suder Klettlinger and Angela Surgenor \\ National Aeronautics and Space Administration \\ Glenn Research Center \\ Cleveland, Ohio 44135 \\ Chia Yen \\ University of Toledo \\ Toledo, Ohio 43606
}

\begin{abstract}
Fischer-Tropsch (F-T) jet fuel composition differs from petroleum-based, conventional commercial jet fuel because of differences in feedstock and production methodology. Fischer-Tropsch fuel typically has a lower aromatic and sulfur content and consists primarily of iso and normal parafins. The ASTM D3241 specification for Jet Fuel Thermal Oxidation Test (JFTOT) break point testing method was used to test the breakpoint of a baseline conventional Jet A, a commercial grade F-T jet fuel, and various blends of this F-T fuel in Jet A. The testing completed in this report was supported by the NASA Fundamental Aeronautics Subsonics Fixed Wing Project.
\end{abstract}

\section{Background}

Fischer-Tropsch (F-T) jet fuel composition differs from the petroleum-based, conventional commercial jet fuel because of differences in feedstock and production methodology. F-T jet fuel is expected to be more stable than conventional jet fuel at elevated temperatures, thus offering a potentially cleaner burning fuel with better thermal stability characteristics. One method to quantify the fuel's oxidative thermal stability is to measure the fuel's breakpoint in accordance with ASTM D3241 specification test known as Jet Fuel Thermal Oxidation Test (JFTOT) (Ref. 1).

JFTOT assesses fuel thermal degradation by two means: one by the heated tube's discoloration due to hydrocarbon coating, the other by determining a filter pressure drop (dp) due to particulate formation. Aerated fuel flows at $3 \mathrm{cc} / \mathrm{min}$ over an electrically heated tube at a preset temperature for $150 \mathrm{~min}$. At the end of the test, the tube is removed from the test stand and visually examined. The tube is inserted into a Visual Tube Rater (VTR) which is an internally lit black box consisting of a standard ASTM color chart. The tube is optically compared to the color chart and is assigned a color number ranging from 1 to 4 ( 1 is metallic silver, 2 is slightly tan, 3-4 are brown). A tube color of 3 or less constitutes a pass. Fuel degradation forms particulates which are collected on a filter, and leads to a higher filter dp over the test period. 25 $\mathrm{mmHg}$ is the maximum pressure drop permitted over the full 150 min test for a fuel to pass the test. Both the tube color ( $<=3$ ) and the $\mathrm{dp}(<=25 \mathrm{mmHg}$ ) are required for passing the JFTOT; if either fails, the JFTOT is considered a failed test. To determine the fuel's breakpoint, the fuel is tested at $5{ }^{\circ} \mathrm{C}$ increments from 260 ${ }^{\circ} \mathrm{C}$. Breakpoint is defined as the highest temperature at which the fuel passes the JFTOT.

\section{Experiment}

The thermal stability test laboratory located in the B109 Alternative Fuels Research Laboratory (Ref. 2) houses a Hot Liquid Process Simulator (HLPS), model HLPS-400 manufactured by Alcor (Ref. 3). The HLPS is designed to determine jet fuel breakpoint according to the test method outlined in ASTM D3241 (Ref. 1). The HLPS unit is located inside of a fume hood (see Fig. 1) and requires water for cooling, gaseous nitrogen to pressurize the reservoir and Zero Air to aerate the fuel before conducting a test. The HLPS unit is connected to a PC which is used for data acquisition and control purposes. 


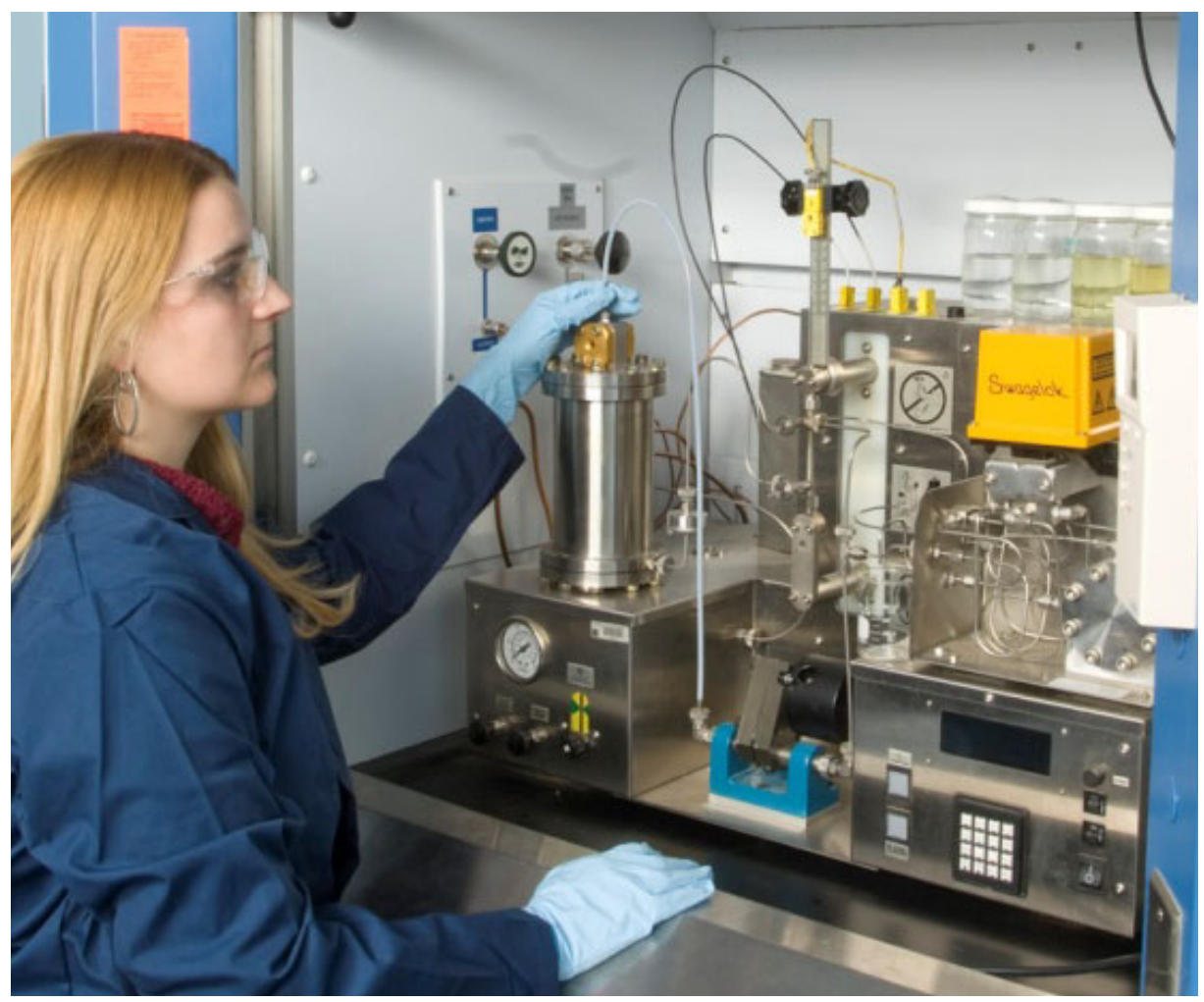

Figure 1.- Hot Liquid Process Simulator inside of fume hood in room 102.

The HLPS components are mainly constructed of stainless steel. The HLPS is capable of testing fuel thermal stability at temperatures up to $650^{\circ} \mathrm{C}$. Various types of heater tubes can be used in order to reach temperature requirements for each individual test. JFTOT tests require the use of an aluminum tube, which has a limit of $380^{\circ} \mathrm{C}$. Steel or stainless steel tubes are also available for tests needing to reach higher temperatures of up to $650^{\circ} \mathrm{C}$. The fuel flow rate can be varied from 0.25 to $5 \mathrm{~mL} / \mathrm{min}$ for each test.

The HLPS was used to evaluate the breakpoint temperature for pure Jet A, pure F-T jet fuel, and various blends (by volume) of these two fuels (10, 30, 50, 70, and 90 percent F-T fuel). JFTOT breakpoint testing procedures were followed except at higher temperatures, where a steel tube was used. Aluminum is the standard tube type for JFTOT testing, however it is not stable above $380{ }^{\circ} \mathrm{C}$ and the steel tube was required for the higher temperatures. A fuel sample was loaded into a stainless steel reservoir. The fuel reservoir was pressurized to 500 psig with gaseous nitrogen and set to a constant flow rate of $3 \mathrm{cc} / \mathrm{min}$. The HLPS pumped the fuel through a resistance heated tube-in-shell heat exchanger while monitoring flow, temperature, and pressure. At the outlet of the reservoir, the fuel flowed through a prefilter and then over the heated tube. The heated tube was ramped up to a target temperature with minimal temperature variation (specified in test procedure) for each test, providing a stable "soak" temperature. At the outlet of the heated tube, a small disposable filter was in place to capture particulates which were formed during the heating process. The HLPS analyzer measured and recorded the pressure drop over this filter throughout the test duration.

As previously discussed, the JFTOT procedure uses two components to evaluate a test: tube color and maximum change in filter differential pressure, both of which can be evaluated using the HLPS. Each HLPS run result was ranked as pass/fail. Each test required approximately $500 \mathrm{~mL}$ of fuel; however multiple tests are required to determine the breakpoint temperature. If a test was completed with a "pass" rating on tube color and pressure drop, a new batch of the same fuel was retested at an increased temperature increment of $5^{\circ} \mathrm{C}$. This process was repeated until a failure occurred. The highest 
temperature with a "pass" rating was considered the breakpoint temperature for the specific fuel or fuel blend.

\section{Results and Discussion}

F-T jet fuel is expected to be more stable at elevated temperatures, thus offering a potentially cleaner burning fuel with better thermal stability characteristics. Fuel analysis results on F-T and Jet A fuel are shown in Table 1.

TABLE 1.-FISCHER-TROPSCH AND JET A FUEL ANALYSIS RESULTS

\begin{tabular}{|c|c|c|}
\hline Test & F-T & Jet A \\
\hline Total Acid Number (mg KOH/g) & 0.002 & 0.00 \\
\hline Aromatics (\% vol) & 0.0 & 19 \\
\hline Mercaptan Sulfur (\% mass) & 0.000 & 0.000 \\
\hline Total Sulfur (\% mass) & 0.00 & 0.0 \\
\hline \multicolumn{3}{|l|}{ Distillation } \\
\hline Initial Boiling Point $\left({ }^{\circ} \mathrm{C}\right)$ & 149 & \\
\hline $10 \%$ Recovered $\left({ }^{\circ} \mathrm{C}\right)$ & 162 & 180 \\
\hline 20\% Recovered $\left({ }^{\circ} \mathrm{C}\right)$ & 163 & \\
\hline $50 \%$ Recovered $\left({ }^{\circ} \mathrm{C}\right)$ & 168 & 212 \\
\hline 90\% Recovered $\left({ }^{\circ} \mathrm{C}\right)$ & 184 & 251 \\
\hline End Point $\left({ }^{\circ} \mathrm{C}\right)$ & 196 & \\
\hline Residue (\% vol) & 0.9 & 1.3 \\
\hline Loss (\% vol) & 0.4 & 0.9 \\
\hline Flash Point $\left({ }^{\circ} \mathrm{C}\right)$ & 44 & 51 \\
\hline API Gravity at $60^{\circ} \mathrm{F}$ & 60.5 & \\
\hline Freezing Point $\left({ }^{\circ} \mathrm{C}\right)$ & -55 & -48 \\
\hline Viscosity at $-20^{\circ} \mathrm{C}\left(\mathrm{mm}^{2} / \mathrm{s}\right)$ & 2.6 & 5.2 \\
\hline Net Heat of Combustion (MJ/kg) & 44.2 & \\
\hline Hydrogen Content (\% mass) & 15.6 & \\
\hline Smoke Point (mm) & 40.0 & 21 \\
\hline Copper Strip Corrosion (2 h at $\left.100^{\circ} \mathrm{C}\right)$ & $1 \mathrm{a}$ & \\
\hline $\begin{array}{l}\text { Thermal Stability at } 260^{\circ} \mathrm{C} \\
\text { Change in Pressure (mmHg) } \\
\text { Tube Deposit Rating, Visual }\end{array}$ & $\begin{array}{l}0 \\
1\end{array}$ & $\begin{array}{l}1 \\
0\end{array}$ \\
\hline Existent Gum (mg/100 mL) & $<1$ & 0.2 \\
\hline Particulate Matter (mg/L) & 0.4 & 0.2 \\
\hline Filtration Time (min) & 2 & \\
\hline Water Reaction Interface Rating & 1 & 1 \\
\hline FSII (\% vol) & 0.00 & 0.00 \\
\hline Conductivity (pS/m) & 217 & 10 \\
\hline Lubricity Test (BOCLE) Wear Scar (mm) & 0.75 & \\
\hline Net Heat of Combustion (MJ/kg) & 44.0 & 43.2 \\
\hline Workmanship & Pass & Pass \\
\hline
\end{tabular}

Figure 2 shows the breakpoint measurements for Jet A, F-T jet fuel, and blended mixtures of Jet A and F-T jet fuel. The different colored bars are repeat testing at the same blend of fuel. Blended results indicate that the fuel thermal stability break point is not linearly related to the fuel blending ratio. Results show that the thermal stability of a 50 percent Jet A/50 percent F-T fuel blend is consistent with that of less stable Jet A fuel. Even a sample of 30 percent Jet A/70 percent F-T blend does not result in a significantly higher breakpoint. A major difference in break point data is first noticed at a mixture of 90 percent F-T fuel. Fuel blends with less than 90 percent F-T fuel have fuel breakpoints consistent with that of less stable Jet A fuel. This is indicative that the breakpoint is dependent on minor fuel component degradation, not a bulk property. Three repeated tests on the same fuel/fuel blends confirmed that typical breakpoint test resulted in a maximum of $10^{\circ} \mathrm{C}$ variation. 


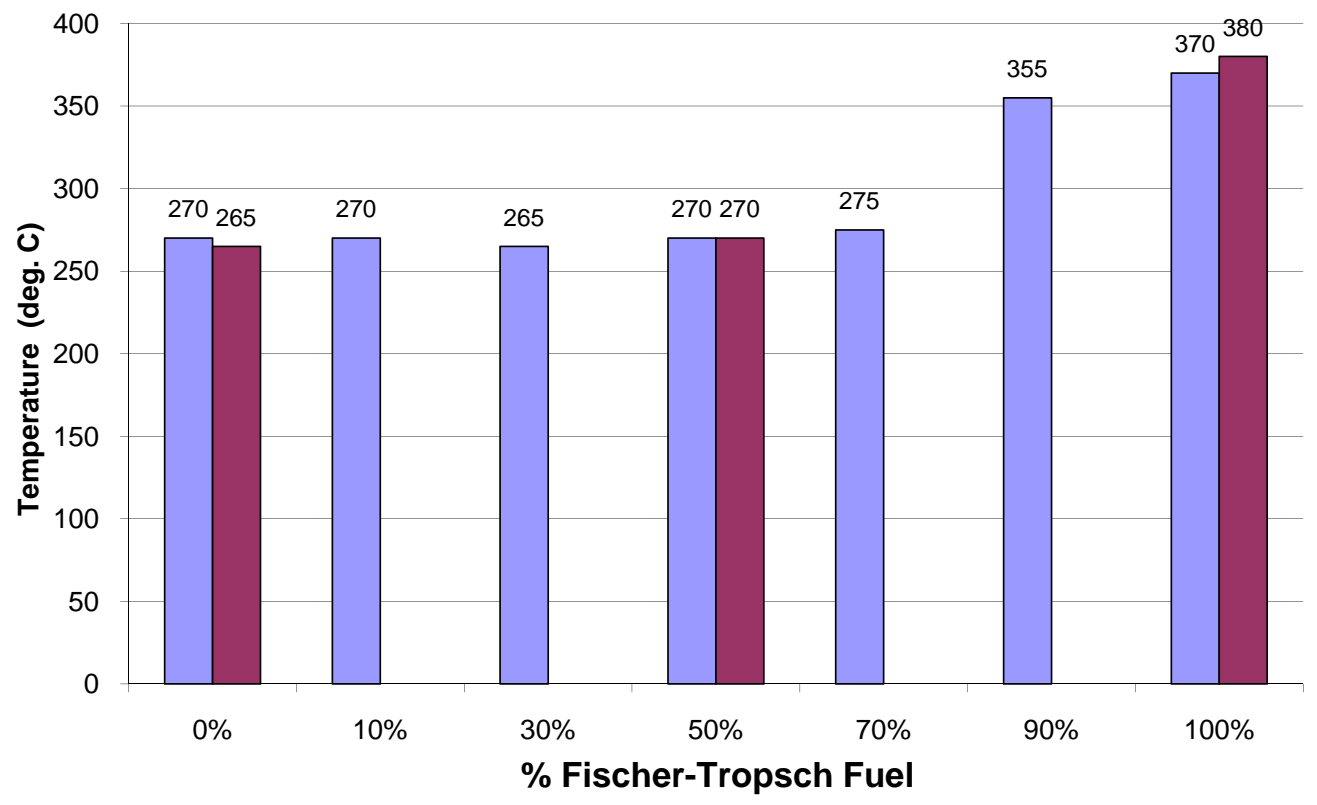

Figure 2.-Thermal stability breakpoint data for F-T Jet fuel and blended mixtures in Jet A fuel.

It is likely that Jet A produced a higher quantity of particles or the particles produced were larger. After testing, sample tubes were cut apart and examined by an optical microscope for both Jet A and F-T Jet fuel. Photographs of the heated tube surfaces are shown in Figure 3. It appears that larger particles are found on the heated tube surface with Jet A in comparison to F-T fuel, although further investigation is required to validate. The material properties of the tube surface may also make a difference. Figure 3 shows major differences in the aluminum tube surface versus the steel tube surface, both tested with F-T fuel. This may indicate that the fuel interacts with the tube surface differently, thus requiring a different "tube color" or tube coating rating when different tube types are used.

Optical images in Figure 3 indicate that there may be major differences between the tube surface composition and how the particulates form on the surface of the tube. These surface differences may affect the tube discoloration upon heating and its subsequent failure ranking; a different scale may be needed for measuring the tube color failure of a steel tube versus an aluminum tube. Since the VTR is designed to test for JFTOT color schemes for aluminum tubes, it may or may not be a valid test for the steel tubes because of the difference in tube properties. Figure 4 shows the optical images of clean tube surfaces at magnifications of 1 and $5 \mathrm{kx}$.

The clean tube optical images show the different surface characteristics. This observation leads us to believe that heated fuel may react differently on the steel tube versus the aluminum tube.

Figure 5 displays some previous data shown in Figure 2 but indicates the type of failure. It should be noted that petroleum based (100 percent) Jet A breakpoints were reached because of high filter pressure drop after the heated tube. The 100 percent F-T fuel breakpoints were not triggered by pressure drop, but by tube surface discoloration. F-T fuel seems to produce less particulate at elevated temperatures in comparison to the conventional Jet A. Typical JFTOT test only requires one of the criteria tests to fail for the complete test to be a failure. Since the validity of color rating on the steel tube is unknown, this may indicate that F-T fuel has a higher breakpoint temperature than observed per criteria stipulated in ASTM D 3241. Since JFTOT is a standardized test method developed and intended to be used with aluminum tubes, a new standardized method may be required for testing at temperatures above $380^{\circ} \mathrm{C}$. 


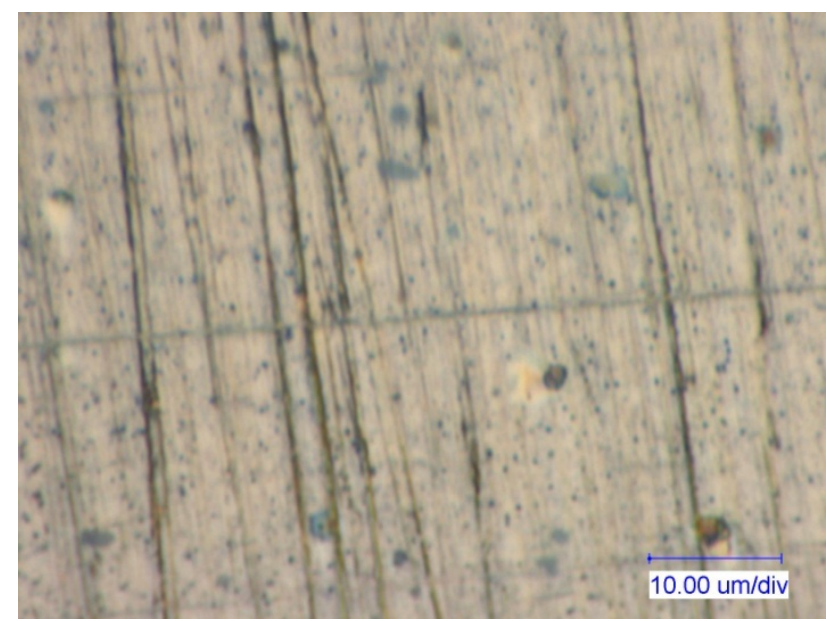

Jet A-aluminum tube (passed)

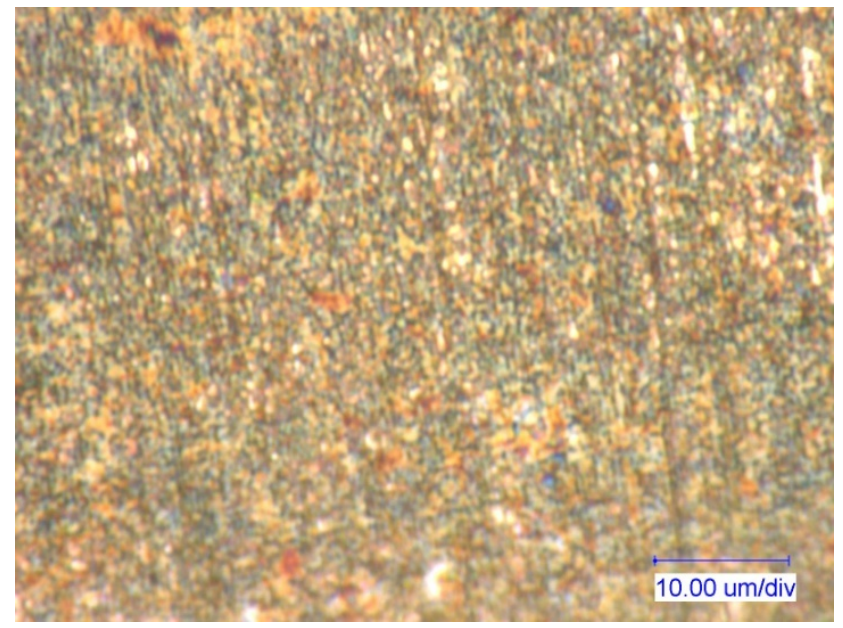

F-T fuel-aluminum tube (passed)

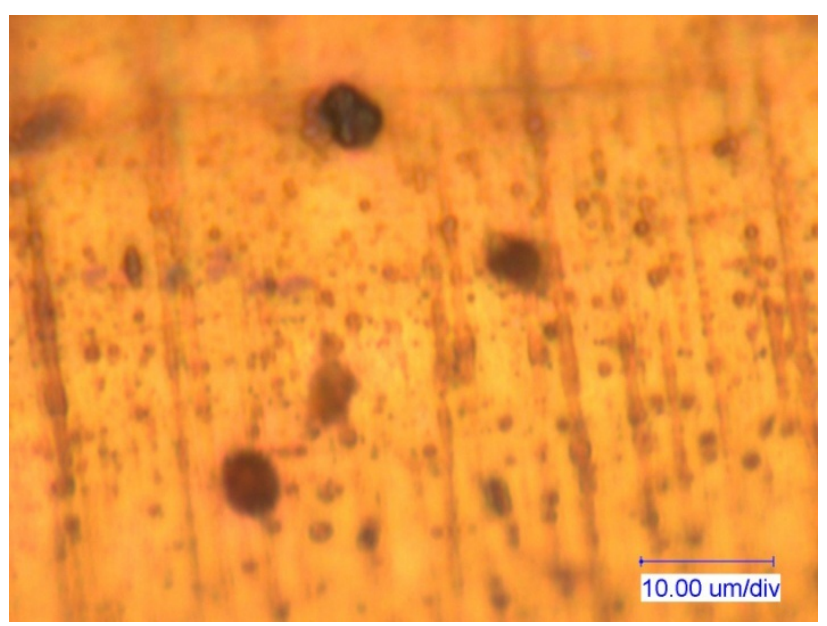

Jet A-aluminum tube (failed)

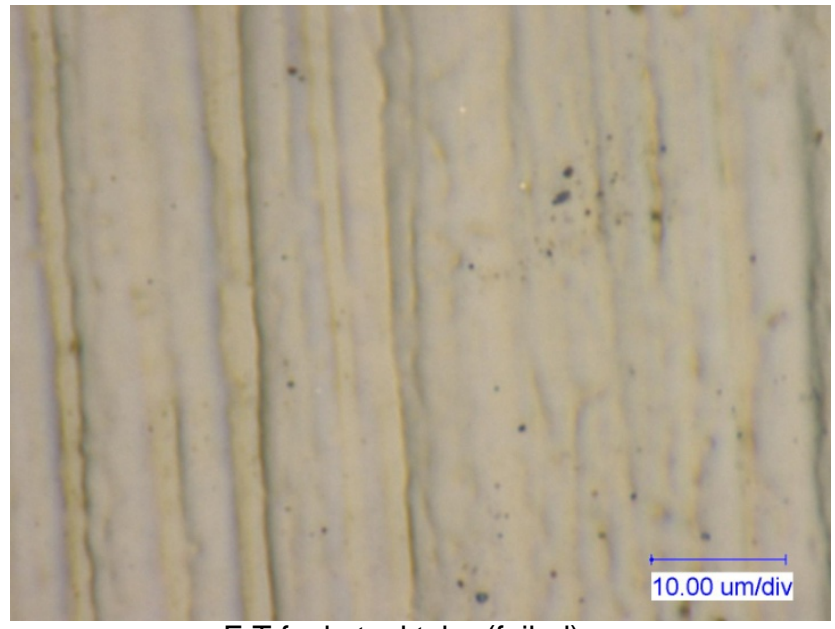

F-T fuel-steel tube (failed)

Figure 3.-Optical images of tubes used during testing. 


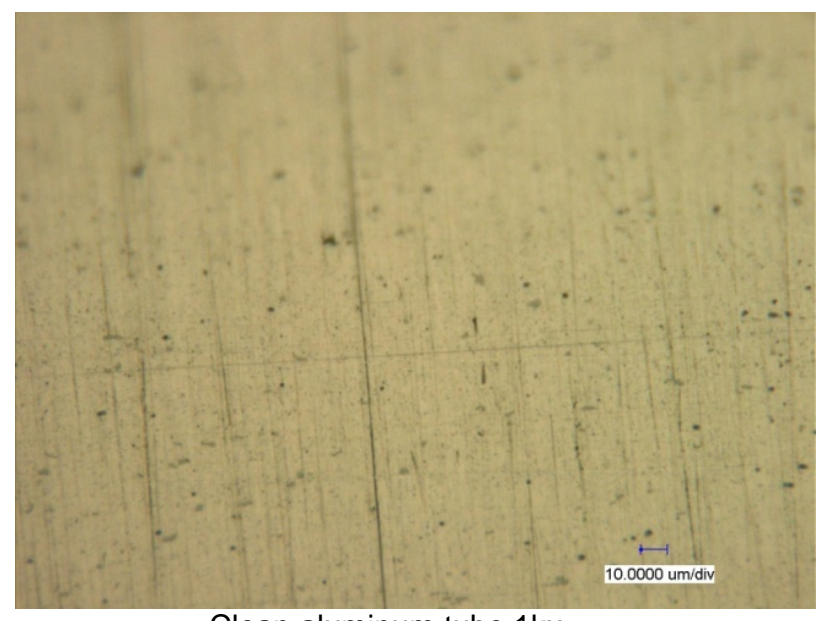

Clean aluminum tube $1 \mathrm{kx}$

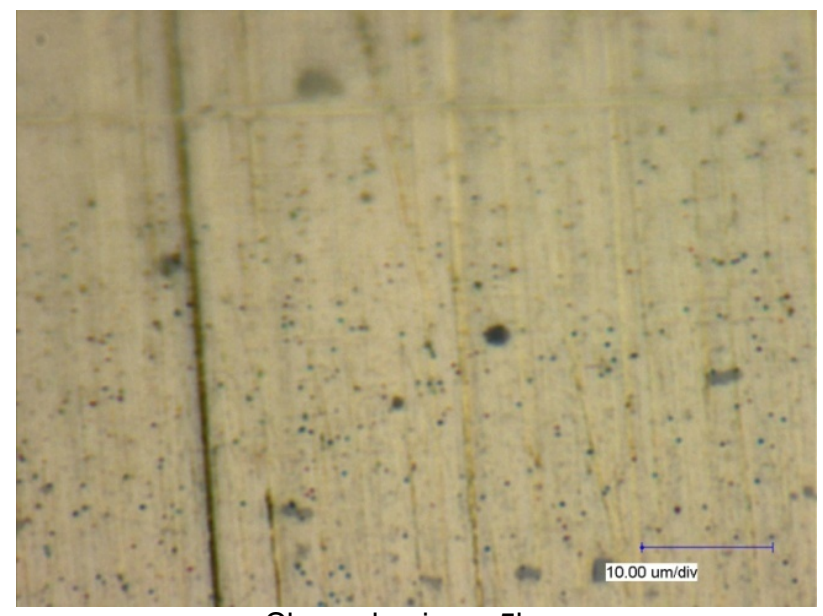

Clean aluminum $5 \mathrm{kx}$

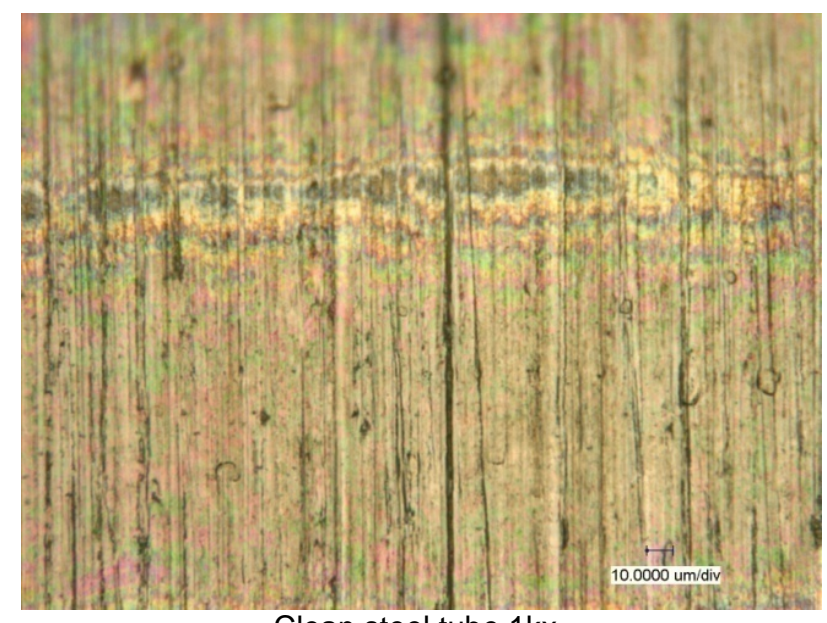

Clean steel tube $1 \mathrm{kx}$



Clean steel tube $5 \mathrm{kx}$

Figure 4.-Optical images of clean tube surfaces-comparison of aluminum to steel. 


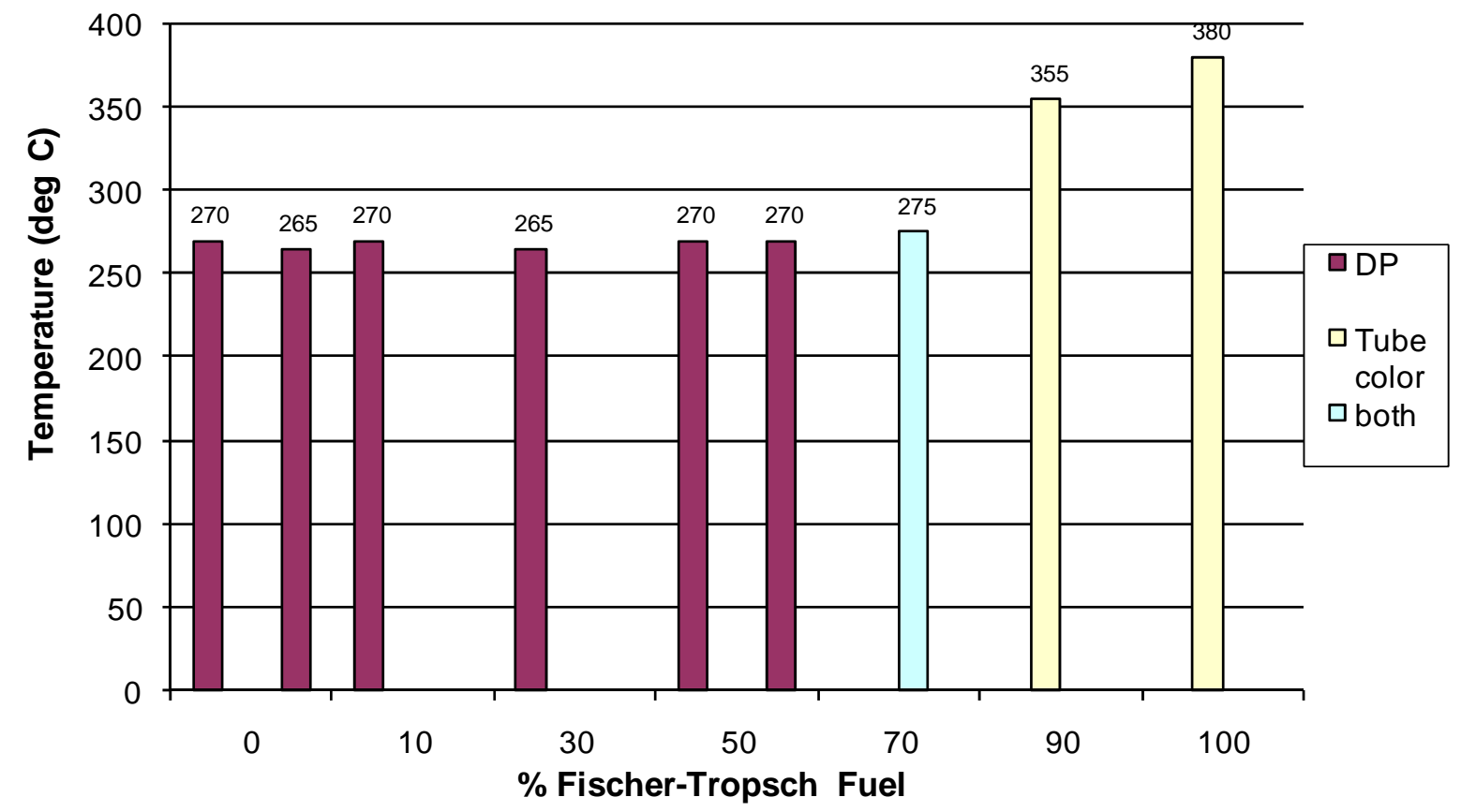

Figure 5._F-T fuel thermal stability breakpoint based on type of failure.

\section{Summary and Conclusions}

A conventional jet fuel, Jet A, was tested as a baseline fuel and its breakpoint was determined to be $270{ }^{\circ} \mathrm{C}$. The breakpoint for F-T jet fuel was determined using a F-T fuel made by a natural gas feed stock (Gas to Liquid- GTL process) and was determined to be at least $370{ }^{\circ} \mathrm{C}$. The F-T based jet fuel proves to be more thermally stable than the conventional Jet A with a breakpoint that is at least $100{ }^{\circ} \mathrm{C}$ higher than Jet A. Optical images have given insight to possible testing differences in Jet A and F-T breakpoint data. This may indicate that the fuel interacts with the tube surface differently, thus requiring a new tube color rating when using tube types other than aluminum. This would require the modification to the standardized test method or a new test method would need to be created for testing thermal stability at temperatures above $380^{\circ} \mathrm{C}$.

\section{References}

1. ASTM Standard D3241, 2008, "Standard Test Method for Thermal Oxidation Stability of Aviation Turbine Fuels (JFTOT Procedure),” ASTM International, West Conshohocken, PA, 2003, DOI: 10.1520/D3241-08, www.astm.org.

2. NASA/TM-2010-216082, “Alternative Fuels Research Facility,” Feb. 2010, Angela D. Surgenor, Thomas M. Tomsik, Jennifer L. Klettlinger, and Leah Nakley.

3. Alcor-PAC Hot Liquid Process Simulator (HLPS 400) User’s Manual Rev. B, Oct. 2003, Version 5. 


\begin{tabular}{|c|c|c|c|c|c|}
\hline \multicolumn{5}{|c|}{ REPORT DOCUMENTATION PAGE } & $\begin{array}{c}\text { Form Approved } \\
\text { OMB No. 0704-0188 }\end{array}$ \\
\hline \multicolumn{6}{|c|}{ 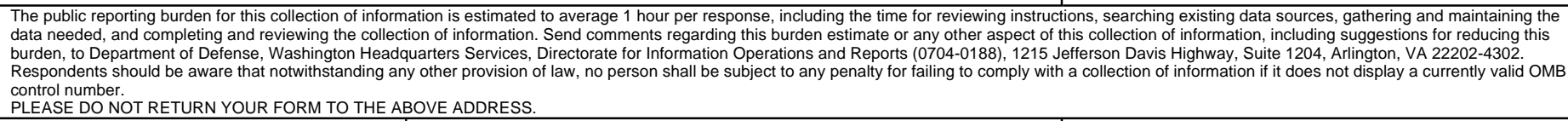 } \\
\hline \multicolumn{2}{|c|}{$\begin{array}{l}\text { 1. REPORT DATE }(D D-M M-Y Y Y Y) \\
01-05-2010\end{array}$} & \multicolumn{3}{|c|}{$\begin{array}{l}\text { 2. REPORT TYPE } \\
\text { Technical Memorandum }\end{array}$} & 3. DATES COVERED (From - To) \\
\hline \multirow{3}{*}{\multicolumn{5}{|c|}{$\begin{array}{l}\text { 4. TITLE AND SUBTITLE } \\
\text { Thermal Stability Testing of a Fischer-Tropsch Fuel and Various Blends With Jet A }\end{array}$}} & 5a. CONTRACT NUMBER \\
\hline & & & & & 5b. GRANT NUMBER \\
\hline & & & & & 5c. PROGRAM ELEMENT NUMBER \\
\hline \multirow{3}{*}{\multicolumn{5}{|c|}{$\begin{array}{l}\text { 6. AUTHOR(S) } \\
\text { Suder Klettlinger, Jennifer; Surgenor, Angela; Yen, Chia }\end{array}$}} & 5d. PROJECT NUMBER \\
\hline & & & & & 5e. TASK NUMBER \\
\hline & & & & & $\begin{array}{l}\text { 5f. WORK UNIT NUMBER } \\
\text { WBS 561581.02.08.03.16.02 }\end{array}$ \\
\hline \multicolumn{5}{|c|}{$\begin{array}{l}\text { 7. PERFORMING ORGANIZATION NAME(S) AND ADDRESS(ES) } \\
\text { National Aeronautics and Space Administration } \\
\text { John H. Glenn Research Center at Lewis Field } \\
\text { Cleveland, Ohio 44135-3191 }\end{array}$} & $\begin{array}{l}\text { 8. PERFORMING ORGANIZATION } \\
\text { REPORT NUMBER } \\
\text { E-17306 }\end{array}$ \\
\hline \multirow{2}{*}{\multicolumn{5}{|c|}{$\begin{array}{l}\text { 9. SPONSORING/MONITORING AGENCY NAME(S) AND ADDRESS(ES) } \\
\text { National Aeronautics and Space Administration } \\
\text { Washington, DC 20546-0001 }\end{array}$}} & $\begin{array}{l}\text { 10. SPONSORING/MONITOR'S } \\
\text { ACRONYM(S) } \\
\text { NASA }\end{array}$ \\
\hline & & & & & $\begin{array}{l}\text { 11. SPONSORING/MONITORING } \\
\text { REPORT NUMBER } \\
\text { NASA/TM-2010-216370 }\end{array}$ \\
\hline \multicolumn{6}{|c|}{$\begin{array}{l}\text { 12. DISTRIBUTION/AVAILABILITY STATEMENT } \\
\text { Unclassified-Unlimited } \\
\text { Subject Category: } 01 \\
\text { Available electronically at http://gltrs.grc.nasa.gov } \\
\text { This publication is available from the NASA Center for AeroSpace Information, 443-757-5802 }\end{array}$} \\
\hline \multicolumn{6}{|c|}{ 13. SUPPLEMENTARY NOTES } \\
\hline \multicolumn{6}{|c|}{$\begin{array}{l}\text { 14. ABSTRACT } \\
\text { Fischer-Tropsch (F-T) jet fuel composition differs from petroleum-based, conventional commercial jet fuel because of differences in } \\
\text { feedstock and production methodology. Fischer-Tropsch fuel typically has a lower aromatic and sulfur content and consists primarily of iso } \\
\text { and normal parafins. The ASTM D3241 specification for Jet Fuel Thermal Oxidation Test (JFTOT) break point testing method was used to } \\
\text { test the breakpoint of a baseline conventional Jet A, a commercial grade F-T jet fuel, and various blends of this F-T fuel in Jet A. The testing } \\
\text { completed in this report was supported by the NASA Fundamental Aeronautics Subsonics Fixed Wing Project. }\end{array}$} \\
\hline \multicolumn{6}{|c|}{$\begin{array}{l}\text { 15. SUBJECT TERMS } \\
\text { Fischer-Tropsch; Breakpoint; Thermal stability; JFTOT; Alternative fuels }\end{array}$} \\
\hline \multicolumn{3}{|c|}{ 16. SECURITY CLASSIFICATION OF: } & $\begin{array}{l}\text { 17. LIMITATION OF } \\
\text { ABSTRACT }\end{array}$ & $\begin{array}{l}\text { 18. NUMBER } \\
\text { OF }\end{array}$ & $\begin{array}{l}\text { 19a. NAME OF RESPONSIBLE PERSON } \\
\text { STI Help Desk (email:help@sti.nasa.gov) }\end{array}$ \\
\hline $\begin{array}{l}\text { a. REPORT } \\
\text { U }\end{array}$ & $\begin{array}{l}\text { b. ABSTRACT } \\
\text { U }\end{array}$ & $\begin{array}{l}\text { c. THIS } \\
\text { PAGE } \\
\text { U }\end{array}$ & UU & $\begin{array}{l}\text { PAGES } \\
13\end{array}$ & $\begin{array}{l}\text { 19b. TELEPHONE NUMBER (include area code) } \\
443-757-5802\end{array}$ \\
\hline
\end{tabular}



